\title{
Disagreements and Conflicts between Scientists and the Crisis of Legitimate Authority: The Case of French New Lockdown in November 2020
}

\author{
Gilles Paché \\ CRET-LOG, Aix-Marseille University \\ 413 Avenue Gaston Berger, 13625 Aix-en-Provence Cedex, France \\ E-mail: gilles.pache@univ-amu.fr
}

Received: November 3, 2020 Accepted: November 25, 2020 Published: November 30, 2020

doi:10.5296/iss.v8i2. URL: http://dx.doi.org/10.5296/iss.v8i2.

\begin{abstract}
The Covid-19 pandemic has plunged the world into a deep health, economic and social crisis whose effects are expected to be felt for several years. In the spring of 2020, faced with the explosion of the number of patients in acute respiratory distress, many countries have implemented a lockdown policy in order to strongly reduce social contacts and slow down the speed of propagation of the coronavirus. This lockdown has been accepted by the populations despite its dramatic economic impact. In the autumn of 2020, after a phase of "summer slackening", a new wave of contamination hit Europe, forcing the political authorities to proceed with a new lockdown, which was very strongly contested, including violently in Spain and Italy. The research note explains the rejection of the new lockdown with reference to Stanley Milgram's experiment on obedience to authority, in particular by indicating that confrontations between scientific experts are at the origin of a profound crisis of legitimacy. Variation \#15 of Stanley Milgram's experiment effectively indicates that in the presence of multiple legitimate authorities, individuals refuse to obey injunctions, which corresponds explicitly to the situation encountered notably in France, with the development of a movement of radical contestation of the new lockdown.
\end{abstract}

Keywords: Covid-19 pandemic, Crisis, France, Legitimate authority, Lockdown, Stanley Milgram's experiment 


\section{Introduction}

Since its first appearance in China in December 2019, Covid-19 has destabilized the entire planet. This infectious disease, qualified as a pandemic by the World Health Organization in March 2020, has a profound impact on the health of populations, the economy and industries worldwide (Baldwin \& Weder di Mauro, 2020). The Covid-19 pandemic will certainly remain as one of the most important crises since the beginning of the Industrial Revolution, perhaps as serious as the 1929 crisis, and it may even have a significant impact on the suicide rates (Sher, 2020). Its economic and social effects are expected to impact the world economy for many years to come, and it is not certain that sectors of activity such as transport or tourism will be able to recover before a decade (Gössling et al., 2021). The most paradoxical dimension of the health crisis is the fact that Covid-19 remains relatively "modest" in terms of its health consequences (its case-fatality rate is well below 1\%), especially when compared to the Spanish flu.

Caused by a virulent strain of the influenza A (H1N1) virus, the Spanish flu, also known as "La Pesadilla", is indeed a pandemic of exceptional severity that took place from January 1918 to December 1920 (Barry, 2005). The influenza virus responsible for Spanish flu is believed to come from birds, which are natural reservoirs for many viruses. This avian virus would then have mutated before infecting humans (Worobey et al., 2014). Most of its victims were young healthy adults, unlike the Covid-19 pandemic, which mainly affected the elderly and/or patients already weakened by serious pathologies (diabetes, morbid obesity, heart failure, etc.). One third of the world's population has been infected with Spanish flu, and given a case-fatality rate of between 10 and 20\%, with peaks at 25\% (Taubenberger \& Morens, 2006), estimates give -depending on the source- between 50 and 100 million deaths worldwide.

In the spring of 2020, the rapid development of the Covid-19 pandemic on almost the world, particularly in Europe and the Americas, led the political authorities to implement a lockdown policy to curb the spread of the contagion. The objective was to drastically reduce social contacts to prevent Covid-19 from being transmitted at such a speed that it would have been impossible to accommodate all the sick persons in hospitals. One after the other, the majority of European countries have thus chosen a more or less strict lockdown policy which has been rather well accepted by the populations, without any real protest to the impediment to freedom of movement. Although the lockdown policy has surprised many citizens, it is not a total novelty (Conti \& Gensini, 2007). Thus, in 1377, Ragusa (Dubrovnik) forbade ships coming from a plague-infested area to enter its port. Very quickly, the Republic of Venice adopted the same measure. The first land quarantine in France was promulgated in 1720 to prevent the plague epidemic - which began in Marseille- from spreading throughout the country.

Despite the hope of a less virulent pandemic, a second violent wave of contagion spread in the fall of 2020, leading the political authorities to once again choose the lockdown option. This "new lockdown" -sometimes called "Act II lockdown" in France- is certainly much less strict than the first lockdown, by multiplying the number of exemptions in Europe, for example in order to go to the workplace or by keeping elementary schools, and junior and senior high schools open. However, the new lockdown is the object of strong criticism, accompanied by 
very brutal street demonstrations in Spain and Italy (see Box 1). The rejection of the new lockdown, although much less coercive, seems surprising and deserves an investigation to try to understand the reasons for it. One of the possible explanations is the rise of "medical populism", to use Lasco's (2020) expression, in other words the questioning by politicians of the power of the "establishment", giving the "people" the right to challenge the word of experts, even violently, as has been seen in the United States or Brazil. This "medical" populism is clearly favored by skepticism of science, certainly present before the health crisis, but which accelerated during its development (Dornan, 2020).

\section{Box 1. A wind of revolt in Italy}

In response to the resurgence in the number of daily contaminations, the Italian government has imposed a "semi-lockdown": a curfew in several major regions, the closure of bars and restaurants at 6 p.m., as well as the closure of sports, movie theaters and concert halls. Immediate consequence: some revolts against the new lockdown have started in Italy. A movement of angry small entrepreneurs, restaurateurs and shopkeepers, born on October 24 in Naples against the restrictions on the operation of their businesses, quickly became radicalized. On the night of October 27, 200 neo-fascist militants of the Forza Nuova group unleashed an urban guerrilla war in Rome against the police, before new clashes during the next week.

Source: Adapted from La Croix, November 3, 2020.

This research note adopts a different perspective to understand the rejection of the new lockdown with reference to work conducted in social psychology and psychological economics as a part of behavioral economics (Buheji, 2019). More specifically, the present contribution analyzes the rejection based on the experiment conducted by Stanley Milgram on obedience to authority in the early 1960s, which has been replicated in many political and social contexts around the planet. The Stanley Milgram's experiment is now well known, and one of its conclusions may provide an explanatory framework for the fierce resistance that the new lockdown is provoking in a large number of sectors of activity - but also among citizens- who had nevertheless accepted the first lockdown during the spring 2020. The specific French context is chosen as a field for analyzing the crisis of legitimacy of scientific (medical) authority, which is at the origin of a protest movement that threatens the foundations of democracy.

\section{Stanley Milgram's Experiment}

A researcher in social psychology at Yale University, after a $\mathrm{PhD}$ at Harvard University, Stanley Milgram conducted a laboratory experiment between 1960 and 1963 with the aim of evaluating the influence that a scientist, in other words an expert in his/her field, can exert on the behavior of an individual. In other words, it is a question of measuring as closely as possible the power of authority between two individuals, a question that is so essential in democratic societies. The final results are published in a landmark book: Obedience to authority: an experimental view (Milgram, 1974/2017). Of course, as with all scientific research, some limits 


\section{Macrothink}

have been underlined at the conclusions that Stanley Milgram drew from his experiment, for example by underestimating the happiness of participants at having contributed to better scientific knowledge, especially in the service of the prestigious Yale University (Haslam et al., 2015).

From a methodological point of view, the approach was based on the recruitment of 636 male volunteers, aged between 20 and 50, through a press advertisement in the local newspaper of the city of New Haven, in return for modest remuneration (4,5 \$, or around 34 \$ in 2020), to participate in a "scientific experiment" on memory conducted within the luxury psychology laboratory of the University (see Fig. 1). Following a rigged draw, one of Stanley Milgram's accomplices (A) finds himself in the situation of an individual who has to memorize a list of word associations (of the type "If I say White, you say ... Snow", or "If I say Sea, you say ... Legs"), ginned up by a questioner (Q) who, for his part, knows nothing about manipulation. The accomplice is strapped to a chair to avoid any disorderly movement and wearing fake electrodes, while a scientist (expert) (S) supervises the experiment, wearing a white coat, which is supposed to symbolize scientific authority. After witnessing the installation of the Stanley Milgram's accomplice, the questioner is introduced to a room in the laboratory where he is seated in front of an impressive shock stimulator.

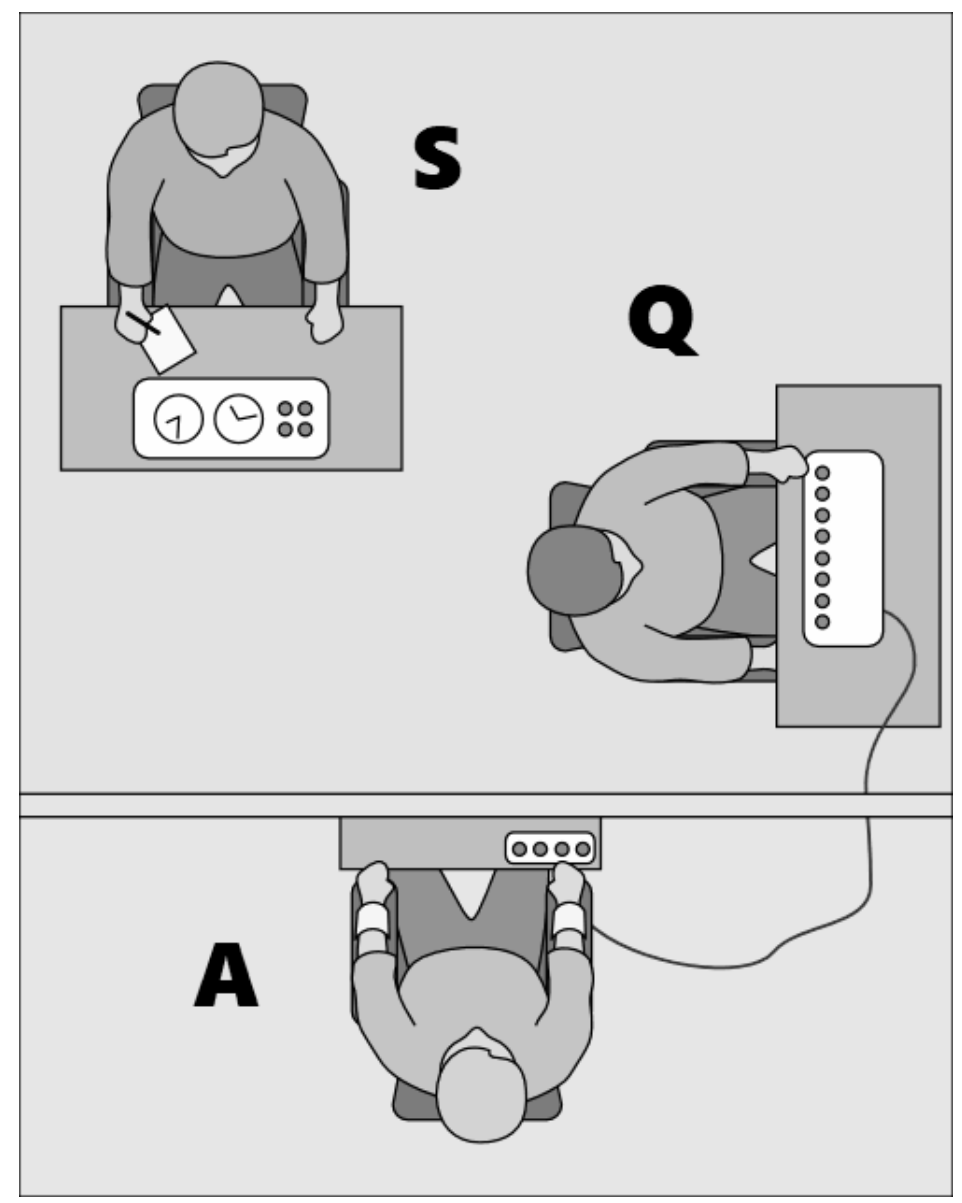

Figure 1. Physical organization of the experiment 


\section{Mll Macrothink}

The questioner is instructed to send an electric shock to the accomplice for every mistake he makes in word association; the more mistakes he makes, the more the intensity of the discharges increases, from 15 volts to 450 volts (the enigmatic mention "XXX" is indicated under the 435- and 450-volt gradations to point out unknown consequences concerning the health of A). Of course, no real torture, just a simulacrum of A, but thanks to real acting skills, Stanley Milgram's accomplice express increasing suffering as he makes mistakes that he commits voluntarily (for examples, with "White" ... "Wall", or with "Sea" .. "Fever"). The groans are followed by shouts, screams and pleas, and even cries of agony from a 285-volt discharge, before long silences reminiscent of a syncope of Stanley Milgram's accomplice. Step by step, the questioner is faced with a very trying moral choice: either to renounce his free will by continuing to inflict increasing abuse, or to refuse to obey the orders of a man whose authority he recognizes as a scientist of the University.

In an attempt to find a way out of this dilemma, the questioners try to negotiate with the scientist to stop the experiment, but the scientist refuses any dialogue. In a neutral voice, the scientist repeats a series of sentences, to the end if necessary: "The experiment requires that you continue", "It is essential that you continue", or "You have no other choice you must go on". The observation is terrifying and will make a lot of ink flow in social psychology: in practically two thirds of the cases, the questioner goes to the end of the experiment, encouraged by the scientist, and inflicts a 450-volt discharge to the accomplice, a discharge that he knows to be deadly. Half a century later, Doliński et al. (2017) replicate exactly the experiment in Poland with 80 individuals aged 18 to 69 and achieve levels of obedience to authority even higher than those of Stanley Milgram. The authors' conclusion is that an overwhelming majority of individuals are still willing to electrocute a stranger to death without any moods.

\section{Variation \#15}

With his experiment, Stanley Milgram makes a major advance in social psychology by bringing to light an inconvenient truth: a "normal", even "banal" individual, without any real sadistic inclination, is capable of showing total obedience in the face of an authority he/she considers legitimate, even if the actions carried out pose problems of conscience. At the same time of Stanley Milgram's experiment, Hannah Arendt attended the trial of the Nazi Adolf Eichmann in Israel, from which she would write her famous book Eichmann in Jerusalem (Arendt, 1963/2006). With a very controversial conclusion: the mediocre civil servant Adolf Eichmann, without any stature, even if his eager anti-Semitism is unquestionable (Stangneth, 2014), was subjected to a legitimate power that would make him an actor of one of the greatest genocides in history, along with that of the Armenians in 1915. The concept of the "banality of evil" introduced by Arendt (1963/2006) following the trial of Adolf Eichmann corresponds to a true philosophical rupture because it clearly implies the probable existence of the inhuman in each one of us.

Other research subsequently indicates that obedience to authority is able of explaining a profound alteration in behavior that transforms a "normal" individual into an exemplary executioner. As part of the famous "Stanford prison experiment", Zimbardo (1972) organizes an experiment in which students are invited to stay locked up in a building for fifteen days, 
with students playing the role of guards and the other students playing the role of prisoners. After a few days, guards began to brutalize and humiliate their prisoners, forcing Philip Zimbardo and his team to stop the experiment. He concludes that wearing a uniform and being assigned a role in an unusual place is enough to turn a sympathetic student into a ruthless torturer. Nearly forty years later, Zimbardo (2008) will publish a new book in which he states that the "Stanford prison experiment" explains what happened in Abu Ghraib prison in Iraq, where American soldiers tortured, raped, and sexually abused Iraqi prisoners between October and December 2003. A famous photograph showing a female American soldier pointing at the penises of naked and hooded prisoners lined up against a wall will be the subject of violent debates, even in the United States.

The question of obedience to authority based on the Stanley Milgram's experiment has of course been criticized, as is the case for all scientific research (Helm \& Morelli, 1979; Nissani, 1990; Pigden \& Gillet, 1996; Griggs \& Whitehead III, 2015; Kaposi, 2017; Smeulers, 2020). The most virulent criticism comes from Perry (2013), who interviewed participants in the experiment and consulted Stanley Milgram's archives. She identifies methodological flaws that cast doubt on the experiment's conclusions. For example, it was originally intended that a questioner refusing to apply electric shocks to the victim four times would be considered "resistant" -leading to the end of the experiment. This condition was then gradually abandoned. Perry (2013) thus notes that a questioner gave in to the scientist's orders after 26 requests. While listening to the tapes recorded during Stanley Milgram's experiment confirms obedience to authority, it also highlights the role played by intimidation. Perry (2013) is surprised by the tension and stress experienced by individuals during the experiment. Far from complying without hesitation with the questioner, they seem to be confronted with much greater pressure and injunctions than the official reports of the Stanley Milgram's experiment suggest.

However, it is important to note that Stanley Milgram's experiment is not based on a uniform protocol, and depending on the conditions selected, the conclusions are still extremely interesting. Indeed, the Stanley Milgram's is based on 18 "variations". In order to take into account contextual factors that can influence the behavior of individuals, Stanley Milgram thus plays on the physical proximity of the questioner to the person being questioned (the accomplice), on the uniform of the scientist, on the location of the experiment or on the physical framework of the experiment. Variation \#15 will be of particular interest, even if real-life situations are more subtle than behavior following instructions given in a laboratory under the control of scientists. It highlights "disorders" within the scientific authority at the origin of the experiment, and its impact on the questioner's behavior. Concretely, in variation \#15, the questioner is confronted with the contradictory points of view -or contradictory commandsof two legitimate powers: the first scientist refuses to continue the experiment in view of the suffering endured by the accomplice, while the second scientist maintains that it is necessary to continue it at any cost.

Stanley Milgram places 20 individuals in such a situation, and the results obtained are very interesting. As soon as a "double legitimate authority" manifests itself, the individuals take advantage of the disagreement -or even conflict- between experts to stop their participation in the experiment, with only one individual pursuing but giving up after a 150 -volt discharge (see 


\section{Mll Macrothink}

Fig. 2). However, Packer (2008)'s meta-analysis from eight obedience experiments indicates that the 150-volt discharge is the point at which obedience rates decrease, regardless of the accomplice's increasing expressions of pain. In the case of variation \#15, Stanley Milgram draws the conclusion that from the moment when the signal transmitted by an authority considered as legitimate is parasitized by a major disagreement within it (the command is not "intelligible"), the coherence of the hierarchical system is deeply altered, to the point of provoking an exit behavior, to use Hirschman's (1970) terminology. This is in line with the work of Laborit (1977) on human behavior in dominant/dominated relationships. An individual will thus be able to submit to authority, to revolt against authority or to take the wisest decision, in other words, to escape, because any struggle of the dominated is futile given the huge power of influence of the dominant. Escape makes it possible to avoid a state of inhibition of action, and consequently to avoid somatic consequences, which Stanley Milgram notes the presence in certain questioners at the time of high levels of electric shocks.

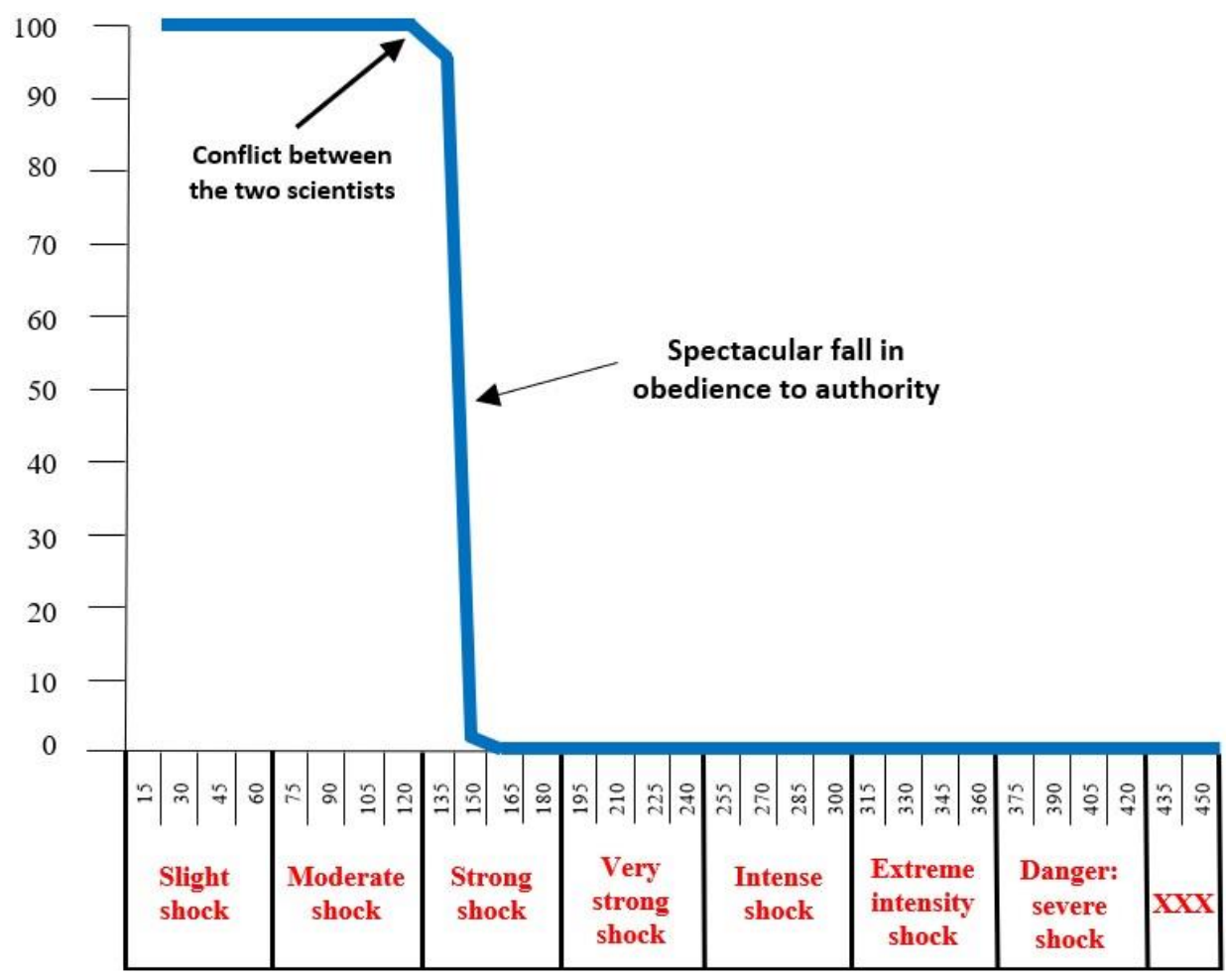

Figure 2. Percentage of participants reaching each level of voltage with double legitimate authority (adapted from Milgram, 1974/2017)

\section{Application to the French New Lockdown}

Can variation \#15 of Stanley Milgram's experiment shed light on the veritable flood of all kinds of disputes generated in France by the new lockdown decision at the end of October 2020 , or even the seditious tendencies of certain mayors who authorized by decree the (illegal) opening of all small businesses in their city? Certainly unintentionally, the battles of experts, sometimes complacently relayed by some TV channels of continuous news/talk program, have opened the way to multiple "exit doors" to refute the merits of the new lockdown, at the very 


\section{Mll Macrothink}

moment when the second wave of the Covid-19 pandemic is a health reality that is hardly questionable. In short, the mistrust of the receiver of the message towards the sender of the message creates an unfavorable emotional state in the communication (Babatunde, 2015). Social networks and digital platforms have also played a significant role in challenging the legitimacy of experts, as underlined by Nguyen \& Catalan-Matamoros (2020:324): "It is true that digital platforms -with their omnipresent algorithm and ability to afford emotional support and bias confirmation - make it so easy for mis/disinformation to travel and to engender illinformed public debates".

It would be enough to convince oneself of the ambient cacophony to sit for three days, eight hours a day, in front of one of the above-mentioned TV channels. The succession of medical experts, but also political experts, makes one dizzy and creates extreme confusion considering the major disagreements expressed, on the most adapted means of protection, on the vectors of contamination, on the use of certain treatments, on the effective implementation of physical distancing, in short on almost everything. To the point of resembling a series worthy of Netflix when Professor Didier Raoult, one of the world's most brilliant researchers in microbiology (the bacteria genus Raoultella is named in his honor), engaged in a battle about the use of hydroxychloroquine against the Parisian elite that was reminiscent of a Marseille vs. Paris soccer match. The case of Professor Didier Raoult is interesting because the polemic is largely based on his personality, namely an unconventional and deliberately provocative researcher (Mucchielli, 2020). In other words, the contradictions between experts escape from the scientific dimension alone and the judgement process is positioned on an experiential interaction in accordance with the fundamentals of behavioral economics (Buheji, 2019).

However, the oppositions between experts go far beyond the anecdotal situation of Professor Didier Raoult. A sample of sentences pronounced in September and October 2020 on the main radio and TV networks in France allows to measure the extent of the differences in judgment between "legitimate authorities" (see Table 1). Indeed, the 12 French experts are recognized by their peers as high-level researchers as indicated by the $h$ index (Bornmann $\&$ Daniel, 2007), having published several hundred papers in their field of expertise. They belong to worldrenowned research centers and, moreover, they are specialized in medical fields directly related to Covid-19: epidemiology, immunology, infectiology, microbiology, physiology, nephrology, and virology. We can thus speak for these 12 experts a virtual scientific legitimacy which justifies a priori their participation in the public debate, but without challenging their true epistemic legitimacy (Lavazza \& Farina, 2020). The diversity of the positions taken can therefore only deeply disturb the citizens, plunged into a situation of major uncertainty with totally contradictory answers.

In the French context, which is even more serious, doctors have often gone beyond the ethical rule that requires a balanced position, as stated in article R4127-13 of the Public Health Code (https://www.legifrance.gouv.fr/codes/article_lc/LEGIARTI000006912874): "When a doctor takes part in a public campaign to protect or promote public health, whatever the nature of that campaign, he/she must refer only to proven facts, observe prudence in his/her statements and be aware of the possible impact of such statements on the general public. On such occasions, he/she must refrain from any form of advertising, either for himself/herself or for institutions 


\section{MInstitute"mk}

in which he/she practices or with which he/she is associated, or in favor of a cause which cannot be considered in the public interest". The alteration of the experts' legitimacy undoubtedly results from a flagrant lack of prudence with high risky statements, but also from a deliberate absence of information on conflicts of interest linked, for example, to the direct payment of substantial remuneration by powerful pharmaceutical laboratories involved in the "race for treatment" against Covid-19. This last point has given rise to ad hominem attacks on social networks like Facebook and Twitter, amplified by the inconsistencies reported in Table 1.

Table 1. Contradictions between French experts about critical dimensions of the health crisis (September-October 2020)

\begin{tabular}{|c|c|c|c|c|c|}
\hline Sentence & Name & Expertise & $h$ index & Date & Media \\
\hline $\begin{array}{l}\text { Sars CoV-2 will probably } \\
\text { become a common cold }\end{array}$ & Y. Gaudin & Virology & 38 & September 9 & $\begin{array}{l}\text { France } \\
\text { Culture }\end{array}$ \\
\hline $\begin{array}{l}\text { Severity indicators in infected } \\
\text { patients are much lower in } \\
\text { September } 2020 \text { than in May } \\
2020\end{array}$ & D. Raoult & Microbiology & 183 & September 14 & Cnews \\
\hline $\begin{array}{l}\text { There is no second wave in } \\
\text { terms of mortality }\end{array}$ & J.-F. Toussaint & Physiology & 39 & September 16 & Sud Radio \\
\hline $\begin{array}{l}\text { The epidemic is behind us, the } \\
\text { virus is not circulating }\end{array}$ & L. Toubiana & Epidemiology & 13 & September 18 & $\begin{array}{c}\text { Radio } \\
\text { Classique } \\
\end{array}$ \\
\hline $\begin{array}{l}\text { It is far too late to contain a } \\
\text { second wave of contamination }\end{array}$ & G. Deray & Nephrology & 55 & October 10 & LCI \\
\hline $\begin{array}{l}\text { One wonders if the Covid-19 } \\
\text { case data are real as they seem } \\
\text { very strange }\end{array}$ & M. Blachier & Epidemiology & 9 & October 16 & LCI \\
\hline $\begin{array}{l}\text { There is an urgent need to take } \\
\text { extremely drastic measures }\end{array}$ & C. Hill & Epidemiology & 47 & October 16 & BFM TV \\
\hline $\begin{array}{l}\text { We are in the process of } \\
\text { inventing a second artificial } \\
\text { wave }\end{array}$ & C. Perronne & Infectiology & 34 & October 25 & Sud Radio \\
\hline $\begin{array}{l}\text { The situation is very difficult; } \\
\text { the quicker action is taken, the } \\
\text { more effective it will be }\end{array}$ & J.-F. Delfraissy & Immunology & 68 & October 26 & RTL \\
\hline $\begin{array}{l}\text { We have lost control of the } \\
\text { epidemic }\end{array}$ & K. Lacombe & Infectiology & 37 & October 26 & LCI \\
\hline $\begin{array}{l}\text { Striking hard at the beginning } \\
\text { is the best strategy to contain } \\
\text { the epidemic }\end{array}$ & A. Fontanet & Epidemiology & 57 & October 28 & Europe 1 \\
\hline $\begin{array}{l}\text { A third wave is expected in the } \\
\text { spring of } 2021\end{array}$ & E. Caumes & Infectiology & 56 & October 29 & BFM TV \\
\hline
\end{tabular}

Source: The author. 
With a very involuntary cruelty, Professor Gilles Pialoux underlines the mistakes and contradictory remarks of some of his/her colleagues, and sometimes friends (Pialoux, 2020), faced with a coronavirus so poorly known as to its characteristics. At a time when social networks are triumphing, the "troubles" within the scientific authority, to use Stanley Milgram's terminology, have thus burst into the open in front of a public that is half worried and half considered. Bjelajac and Filipović (2020) identify at least five major controversies among experts at the heart of the health crisis: the speed of spread of the pandemic; the number of deaths due to the coronavirus alone; the true case-fatality rate; the origins of the coronavirus; and differences in the spread of the coronavirus among populations. No reliable answer could be given. From then on, the experts' words were durably altered, and the result could only be a succession of denials and questioning of the discourse, to the point of a pure and simple refusal of the (collective) rules of the "lockdown game", even though scientific investigations confirm the link between a strict lockdown policy and slowing the spread of the coronavirus (Atalan, 2020; Pachetti et al., 2020; Wong et al., 2020).

The alteration of the legitimacy of experts is now so profound that the contestation of a new lockdown no longer takes place only at the level of citizens and politicians, but also at the level of entire sectors of activity. Why close small bookstores when large food stores can continue to sell books? Don't neighborhood bars play an essential role in maintaining social ties? Is a hairdresser receiving customers in dribs and drabs really an inducer of contagion? We could go on for a long time with the list of possible "exemptions" requested by some experts, which some experts will consider acceptable... and others unacceptable. For example, in June 2020, the British Medical Journal published a short article opposing the views of two scientists on the relevance of using a lockdown policy again, after the first lockdown during spring 2020 (Melnick \& Ioannidis, 2020). The arguments put forward are not conclusive. Interpreted by each party according to its own interests, they can justify two opposing strategies, and in particular a denial strategy. These are the "troubles" of the scientific authority into which several mayors have rushed, as indicated above, for reasons that are certainly electoral (see Box 2).

\section{Box 2. The fronde of French mayors}

Since the first day of the new lockdown, more and more French mayors have signed decrees authorizing non-food businesses to remain open in their cities. These decrees were immediately declared illegal by the national political authorities, but the "arm wrestling" between the mayors and the government appeared to be tense. One of the first to open the fronde is the mayor of Migennes, near Paris, denouncing unfair competition between small downtown stores and large stores outside the city that can still sell food and non-food products. The mayor of Paris promised to commit to keeping bookstores open, and the mayor of Bordeaux called on the government to support small businesses. For their part, mayors and MPs from SeineMaritime signed an open letter, addressed to the Prime Minister and the President Macron to warn of the unequal treatment suffered by small businesses described as non-essential.

Source: Adapted from France Bleu, November 2, 2020. 
The loss of confidence in experts is further amplified by multiple media interventions based on the speakers' ability to convince rather than on their scientific knowledge. The health crisis has confirmed the relevance of the famous Dunning-Kruger effect, which highlights a judgment bias of primary importance at the cognitive level. Based on work carried out within the Department of Psychology at Cornell University, Kruger and Dunning (1999), Duning et al. (2003) and Dunning (2011) identify the tendency for the least competent people in a field to overestimate their knowledges and, conversely, the tendency for the most competent people to underestimate their knowledges. On many TV channels of continuous news/talk program, the capacity of persuasion possessed by incompetent people on the health effects of Covid-19, based on their judgement bias, clearly destabilized the most competent experts -but naturally subject to scientific doubt- to the point of making their balanced positions inaudible. Indeed, as Dunning (2011) points out, as an individual becomes more and more competent, he/she quickly discovers the extent of his/her ignorance. The previously mentioned cacophony, a source of contestation, certainly finds here its deep roots: "The fundamental cause of the trouble is that in the modern world the stupid are cocksure while the intelligent are full of doubt" (Russell, 1933/2009:203).

\section{Discussion and Conclusion}

Fournout (2020) despairs of the controversies on the Covid-19 by evoking the absence of dialogue in the public space, to the profit of "separate speeches, which have any latitude to spread out, but which never meet the opposite speeches". Citing the exasperation of journalist Laurence Ferrari who abruptly interrupted a televised debate between doctors on Cnews channel: "Enough is enough, we are not in a playground, there are millions of French people who are fed up with these dissensions between scientists, to whom [the French] are told everything and anything every day, I assure you that they are fed up". This is undoubtedly one of the most emblematic manifestations of the ongoing de-legitimization of scientific discourse, which is particularly disturbing, even dramatic, because it opens the way to all kinds of populism and relativism elevated to the rank of dogma. Everything then happens as if the individual abandons his/her agentic state of total obedience, as described by Milgram (1974/2017) from his experience -an agentic state in which the individual delegates his/her responsibility to the authority to which he/she blindly obeys.

Over and above its disastrous economic and social consequences, the Covid-19 pandemic has shown us the profound questioning of one of the foundations of democracy: disputatio. In the Middle Ages, in Europe, the disputatio resembled a debate between two or more interlocutors, with an opponens presenting objections to a given position and then a respondens opposing counter-propositions to the first objections, so that a real debate based on an argument developed point by point was established (Périgot, 2007; Weijers, 2007). We can speak here of a "dialectical joust" whose objective was to advance knowledge. It is to be feared that social networks, preferring invective and the diffusion of fake news to the appeased debate, will be a major hindrance on the return to disputatio, and that they will give the opportunity to multiple public and private stakeholders to justify their rejection of democratic systems of decisionmaking. Medical experts are even battling it out in court since Professor Didier Raoult filed a defamation suit against Professors Karine Lacombe and Jean-Paul Stahl in October and 


\section{Mll Macrothink}

November 2020. Drawing on Freud's (1921/1990) psychoanalytical analysis, the risk of seeing the "libidinal bond" between individuals and the elites permanently disintegrate has perhaps never been so high.

However, this research note has two main limitations. The first limitation is linked to the lack of hindsight from the crisis of legitimate authority. In future research, it will be necessary to analyze whether the contestation in the face of the new lockdown corresponds to a "flash in the pan", a spontaneous reaction of anger, or whether the revolt of the masses is lasting, especially with the questioning of the foundations of participatory democracy. The second limitation is linked to the absence of cross-cultural analysis. If the contestation of a new lockdown seems vivacious in the countries of Latin culture, this is not the case in the Nordic countries of Europe, which more easily accept to comply with political decisions. It would be interesting to build on work in multicultural management, particularly following Hofstede (1991, 2003), to examine the specific mechanisms for challenging the word of experts in individualist vs. collectivist cultures. In brief, it is very likely that the Covid-19 pandemic will deeply transform the way in which social systems react to a crisis, and as such, it is essential to study its mechanisms.

\section{Acknowledgments}

The author thanks two anonymous reviewers of Issues in Social Science and Professor Bruno Amann, from Toulouse University (France), for their insightful comments and suggestions which helped to greatly improve the final version of the paper.

\section{References}

Arendt, H. (1963/2006). Eichmann in Jerusalem: A report on the banality of evil. London: Penguin.

Atalan, A. (2020). Is the lockdown important to prevent the COVID-19 pandemic? Effects on psychology, environment and economy-perspective. Annals of Medicine \& Surgery, 56, 38-42. https://doi.org/10.1016/j.amsu.2020.06.010

Babatunde, O. (2015). Importance of effective communication in public organisations. Issues in Social Science, 3(2), 78-89. http://dx.doi.org/10.5296/iss.v3i2.8596

Baldwin, R., \& Weder di Mauto, B. (2020). Economics in the time of COVID-19. London: CEPR Press.

Barry, J. (2005). The great influenza: The story of the deadliest pandemic in history. London: Penguin.

Bjelajac, Z., \& Filipović, A. (2020). Lack of security culture in facing the COVID-19 pandemic. The Culture of Polis, 17, 383-399. Retrieved from https://kpolisa.com/KP42/31BjelajacFilipovic.pdf

Bornmann, L., \& Daniel, H. (2007). What do we know about the $h$ index? Journal of the American Society for Information Science \& Technology, 58(9), 1381-1385. https://doi.org/10.1002/asi.20609 


\section{MInstitute ${ }^{\text {Macrothink }}$}

Buheji, M. (2019). Reviewing implications of "behavioural economics" on our future life. Issues in Social Science, 7(2), 9-17. http://doi.org/10.5296/iss.v7i2.15572

Conti, A., \& Gensini, G. F. (2007). The historical evolution of some intrinsic dimensions of quarantine. Medicina nei Secoli, 19(1), 173-188. Retrieved from http://www.medicinaneisecoli.it

Doliński, D., Grzyb, T., Folwarczny, M., Grzybała, P., Krzyszycha, K., Martynowska, K., \& Trojanowski, J. (2017). Would you deliver an electric shock in 2015? Obedience in the experimental paradigm developed by Stanley Milgram in the 50 years following the original studies. Social Psychological \& Personality Science, 8(8), 927-933. https://doi.org/10.1177/1948550617693060

Dornan, C. (2020). Science disinformation in a time of pandemic. Ottawa: Public Policy Forum.

Dunning, D. (2011). The Dunning-Kruger effect: On being ignorant of one's own ignorance. In Olson, J., \& Zanna, M. (Eds.), Advances in experimental social psychology (Vol. 44, pp. 247296). San Diego, CA: Academic Press.

Dunning, D., Johnson, K., Ehrlinger, J., \& Kruger, J. (2003). Why people fail to recognize their own incompetence. Current Directions in Psychological Science, 12(3), 83-87. https://doi.org/10.1111/1467-8721.01235

Fournout, O. (2020). Controverses sur le Covid-19: Stop ou encore? Atlantico, October 8. Retrieved from https://www.atlantico.fr

Freud, S. (1921/1990). Group psychology and the analysis of the ego. New York: Norton.

Gössling, S., Scott, D., \& Hall, C. (2021). Pandemics, tourism and global change: A rapid assessment of COVID-19. Journal of Sustainable Tourism, 29(1), 1-20. https://doi.org/10.1080/09669582.2020.1758708

Griggs, R., \& Whitehead III, G. (2015). Coverage of recent criticisms of Milgram's obedience experiments in introductory social psychology textbooks. Theory \& Psychology, 25(5), 564580. https://doi.org/10.1177/0959354315601231

Haslam, A. Reicher, S., Millard, K., \& McDonald, R. (2015). "Happy to have been of service": The Yale archive as a window into the engaged followership of participants in Milgram's "obedience" experiments. British Journal of Social Psychology, 54(1), 55-83. https://doi.org/10.1111/bjso.12074

Helm, C., \& Morelli, M. (1979). Stanley Milgram and the obedience experiment: Authority, legitimacy, and human action. Political Theory, 7(3), 321-345. https://doi.org/10.1177/009059177900700303

Hirschman, A. (1970). Exit, voice, and loyalty: Responses to decline in firms, organizations, and States. Cambridge, MA: Harvard University Press.

Hofstede, G. (1991). Cultures and organizations: Software of the mind. New York: McGrawHill. 
Hofstede, G. (2003). Culture's consequences: Comparing values, behaviors, institutions and organizations across Nations (2nd ed.). Thousand Oaks, CA: Sage.

Kaposi, D. (2017). The resistance experiments: Morality, authority and obedience in Stanley Milgram's account. Journal for the Theory of Social Behaviour, 47(4), 382-401. https://doi.org/10.1111/jtsb.12137

Kruger, J., \& Dunning, D. (1999). Unskilled and unaware of it: How difficulties in recognizing one's own incompetence lead to inflated self-assessments. Journal of Personality \& Social Psychology, 77(6), 1121-1134. https://doi.org/10.1037//0022-3514.77.6.1121

Laborit, H. (1977). Decoding the human message. London: Allison \& Busby.

Lasco, G. (2020). Medical populism and the COVID-19 pandemic. Global Public Health, 15(10), 1417-1429. https://doi.org/10.1080/17441692.2020.1807581

Lavazza, A., \& Farina, M. (2020). The role of experts in the Covid-19 pandemic and the limits of their epistemic authority in democracy. Frontiers in Public Health, 8, Article 356. https://doi.org/10.3389/fpubh.2020.00356

Melnick, E., \& Ioannidis, J. (2020). Should governments continue lockdown to slow the spread of Covid-19? British Medical Journal, 369, 1-3. https://doi.org/10.1136/bmj.m1924

Milgram, S. (1974/2017). Obedience to authority: An experimental view. New York: Harper Perennial.

Mucchielli, L. (2020). Que révèle la polémique Raoult? Pratiques: Les Cahiers de la Médecine Utopique, 91, 76-79. Retrieved from https://pratiques.fr

Nguyen, A., \& Catalan-Matamoros, D. (2020). Digital mis/disinformation and public engagement with health and science controversies: Fresh perspectives from Covid-19. Media \& Communication, 8(2), 323-328. https://doi.org/10.17645/mac.v8i2.3352

Nissani, M. (1990). A cognitive reinterpretation of Stanley Milgram's observations on obedience to authority. American Psychologist, 45(12), 1384-1385. https://doi.org/10.1037/0003-066X.45.12.1384

Pachetti, M., Marini, B., Giudici, F., Benedetti, F., Angeletti, S., Ciccozzi, M., Masciovecchio, C., Ippodrino, R., \& Zella, D. (2020). Impact of lockdown on Covid-19 case fatality rate and viral mutations spread in 7 countries in Europe and North America. Journal of Transnational Medicine, 18, Article 338. https://doi.org/10.1186/s12967-020-02501-x

Packer, D. (2008). Identifying systematic disobedience in Milgram's obedience experiments: A meta-analytic review. Perspectives on Psychological Science, 3(4), 301-304. https://doi.org/10.1111/j.1745-6924.2008.00080.x

Périgot, B. (2007). Antécédences: De la disputatio médiévale au débat humaniste. Menini: Travaux \& Documents, 11, 43-61. https://doi.org/10.4000/memini.74 


\section{Macrothink}

Perry, G. (2013). Behind the shock machine: The untold story of the notorious Milgram psychology experiments. New York: The New Press.

Pialoux, G. (2020). Nous n'étions pas prêts: Carnet de bord par temps de coronavirus. Paris: JC Lattès.

Pigden, C., \& Gillet, G. (1996). Milgram, method and morality. Journal of Applied Philosophy, 13(3), 233-250. https://doi.org/10.1111/j.1468-5930.1996.tb00169.x

Russell, B. (1933/2009). Mortals and others: American essays 1931-1935. London: Routledge.

Sher, L. (2020). The impact of the COVID-19 pandemic on suicide rates. QJM: An International Journal of Medicine, 113(10), 707-712. https://doi.org/10.1093/qjmed/hcaa202

Smeulers, A. (2020). Milgram revisited: Can we still use Milgram's "obedience to authority" experiments to explain mass atrocities after the opening of the archives? Review essay. Journal of Perpetrator Research, 3(1), 216-244. https://doi.org/10.21039/jpr.3.1.45

Stangneth, B. (2014). Eichmann before Jerusalem: The unexamined life of a mass murderer. New York: Knopf Doubleday.

Taubenberger, J., \& Morens, D. (2006). 1918 influenza: The mother of all pandemics. Emerging Infectious Diseases, 12(1), 15-22. https://doi.org/10.3201/eid1201.050979

Weijers, O. (2007). The medieval disputatio. In Dascal, M., \& Chang, H.-L. (Eds.), Traditions of controversy (pp. 141-149). Philadelphia, PA: John Benjamins Publishing.

Wong, M., Ng, R., Chong, K.-C., Lai, C., Huang, J., Chen, Z., Boon, S., \& Chan, P. (2020). Stringent containment measures without complete city lockdown to achieve low incidence and mortality across two waves of COVID-19 in Hong Kong. British Medical Journal Global Health, 5(10), 1-9. https://doi.org/10.1136/bmjgh-2020-003573

Worobey, M., Han, G. Z., \& Rambaut, A. (2014). Genesis and pathogenesis of the 1918 pandemic H1N1 influenza A virus. Proceedings of the National Academy of Sciences, 111(22), 8107-8112. https://doi.org/10.1073/pnas.1324197111

Zimbardo, P. (1972). Stanford prison experiment: A simulation study of the psychology of imprisonment. Stanford, CA: Stanford University.

Zimbardo, P. (2008). The Lucifer effect: Understanding how good people turn evil. New York: Random House.

\section{Copyright Disclaimer}

Copyright for this article is retained by the author(s), with first publication rights granted to the journal.

This is an open-access article distributed under the terms and conditions of the Creative Commons Attribution license (http://creativecommons.org/licenses/by/3.0/). 